\title{
Marginalised Ethnic Groups in Accounting Education and Profession: An International Context
}

\author{
Hassan Ibrahim Rkein'1, Sivakumar Velayutham² \\ ${ }^{1}$ Accounting Department, Al Maaref University, Beirut, Lebanon \\ ${ }^{2}$ Nilai University, Nilai, Malaysia \\ Email:Hassan.rkein@mu.edu.lb, sivakumar@nilai.edu.my
}

How to cite this paper: Rkein, H.I. and Velayutham, S. (2018) Marginalised Ethnic Groups in Accounting Education and Profession: An International Context. Open Journal of Accounting, 7, 139-158. https://doi.org/10.4236/ojacct.2018.72010

Received: February 20, 2018

Accepted: April 9, 2018

Published: April 12, 2018

Copyright (c) 2018 by authors and Scientific Research Publishing Inc. This work is licensed under the Creative Commons Attribution International License (CC BY 4.0).

http://creativecommons.org/licenses/by/4.0/

\begin{abstract}
The paper seeks to distill common reasons in the literature for the low participation of indigenous people in accounting education and profession through an international comparison. The study serves as a tool for developing classifications of reasons for low participation and for establishing whether shared reasons can be explained by the same causes. It provides a foundation for the study of low participation of indigenous people in accounting. The study highlights indigenous education in general, indigenous culture, the accounting system and the role of colonization as major impediments to participation and success of indigenous people in accounting.
\end{abstract}

\section{Keywords}

Accounting, Indigenous, Education, Profession, Participation

\section{Introduction}

There is general acknowledgement that the Indigenous peoples in the four main geographical areas of Canada, the United States, Australia and New Zealand were dispossessed of their traditional territory and devastation of their population, their culture and their political, social and economic structures through massive European settlement ${ }^{1}$ (Buhr, 2011) [1]. A growing body of literature that includes the publication of a special issue devoted to examining the interface between accounting and Indigenous peoples in the Accounting, Auditing and Accountability Journal in 2000 (Gallhofer \& Chew, 2000) [2] and a special issue "The terms "European settlers", "settlers" and "English diaspora" will be used interchangeably. Although the settlers arrived from countries in addition to England, it was British Imperialism that prevailed and set the Anglo stamp on Canada, the US, Australia and New Zealand. 
on the role of accounting and empire in Critical Perspectives on Accounting in 2004 (Annisette \& Neu, 2004) [3], documents a role for accounting in enabling this dispossession and devastation.

Whilst history needs to be told if there is to be any understanding and redress for past and present injustices there is a growing recognition that it is time to envision a more positive future for Indigenous peoples (Smith, 1999) [4] and along with that vision, a more positive role for accounting. Helin (2008) [5], one of Canada's best known Aboriginal lawyers urges a new discourse based on action, moving forward with a real strategy, about creating a polity that is fair and widely-accepted to the indigenous grassroots, and the development of an economy that leads to self-reliance (p. 172).

Buhr (2011) [1] observes that there is one publication in the literature that deals with the theme of Indigenous peoples and the accounting profession, McNicholaset et al. (2004) [6] and the future well-being of Indigenous peoples will require the development of professional skills in using accounting techniques. Since accounting has been identified as a tool for domination and dispossession, accounting probably should also be able to play a role in a strategy moving forward towards the development of an economy that leads to self-reliance. It can therefore be argued that one approach to overcoming domination and dispossession would be a better understanding of accounting by Indigenous peoples through participation in accounting education and profession.

The participation of Indigenous peoples in accounting education and profession is, however, very low. A study by Rkein and Norris (2012) [7] indicates that there were only about nine Indigenous qualified accountants in Australia. The participation of indigenous people in other countries with a high proportion of European settlers like the United States, Canada, New Zealand, and South Africa is just as low (Hammond and Streeter, 1994 [8]; Hammond, 1997 [9]; Holmes et al., 2005 [10], Preston, 2006 [11]; Hooper and Pratt, 1995 [12]; Hammond et al., 2007 [13]; Mitchell and Flintall, 1990 [14]; and Jacobs, 2000 [15]).

Whilst there is considerable evidence of the low participation of indigenous people in accounting education and the profession, the level of evidence in the different countries is uneven and there have been no comparative studies to identify whether the experiences are common. An international comparative study would serve as a tool for developing classifications of reasons for low participation and for establishing whether shared reasons can be explained by the same causes (Hantrais, 1995) [16]. The study would also identify gaps in the knowledge and point to possible new directions and perspectives that could be followed. The paper looks at five major countries: four (United States, Canada, Australia and New Zealand) where the indigenous people are a minority and South Africa where indigenous people are a majority, but with a substantial proportion of European settlers.

The rest of the paper is organised as follows. The next section provides an overview of the level of under-representation of indigenous people. Section three provides a brief review of European settlement and examines the literature on 
the barriers to indigenous participation in accounting education in the individual countries. In section four this literature is summarized according to five prominent themes, followed by a discussion of the factors leading to the development of this stream. In section five our understanding of the under-representation of indigenous people in accounting educations is reviewed and gaps in our knowledge identified followed by possible new directions for research.

\subsection{Under-Representation}

The under-representation of minority ethnic groups and Indigenous peoples in accounting education and in the profession is a fact that exists in all of the above mentioned countries, although the rate differs from one country to another. For instance, according to Mitchell and Flintall (1990) [14], in 1989 the number of black Certified Public Accountants (CPA's) was no more than 1\% of all American CPA's, knowing that $1 \%$ in the United States represented approximately 2500, noting that African Americans represent 12\% of the population in the United States. This study relied on data that were published at different dates since it is main objective was to highlight the under-representation irrespective of the date. The factors that surrounded those dates received the most attention.

In South Africa the first black female to qualify as a charted accountant (CA) did not happen until 1998, when Sindiswa Zilwa fully qualified as a CA. Additionally, and not very different from the United States, on $31^{\text {st }}$ March 2001 only $1.06 \%$ of all South African Charted Accountants were black, which means that there were only 207 Black CAs out of a total of 19,493 South Africa Charted Accountants (Sadler, 2002) [17], it should also be noted that although this number might sound undersized to the reader, this is in fact the result of an increase of 170\% CA's since 1994, when South African Black Charted Accountants only accounted for 77 CA's.

Furthermore, the situation in the United States and South Africa is not unique, as Canada also has a similar situation, as there are 1640 members in their Aboriginal Financial Officers Association which was established in 2000. Nevertheless, it should be noted that this number is gradually growing. For instance, within one year: from $28^{\text {th }}$ February 2010 until the $28^{\text {th }}$ February 2011, the number of members grew from 1492 to 1640, which means a boost of $9.9 \%$ (Aboriginal Financial Officers Association, 2011) [18]. New Zealand is also suffering from the under-representation of its indigenous people, the Maori people in the accounting profession (McNicholas, et al., 2004) [4]. In new-Zealand, the situation appears worse than the previously listed countries as the need for accounting and management skills was not recognised by the Maori community until recently, and, as a result, Maori people have not yet entered the accounting profession in significant numbers (Ministry of Maori Development, 1999) [19]. New Zealand Institute of Chartered Accountants (NZICA) (2013) [20] Annual Report shows that $0.8 \%$ of NZICA members identify themselves as Maori. In comparison to the other countries discussed in this paper, the Australian accountancy 
profession and its organisations are noted for their multi-cultural/multi ethnic nature. However, the marginalised ethnic groups of Aboriginal and Torres Strait Islanders are, like the Indigenous groups in the other countries, under-represented in accounting education and in the profession. With an estimate of only nine in whole of Australia (Rkein \& Norris, 2012) [7].

The following Table 1 shows the low participation in the accounting profession within marginalised ethnic groups and Indigenous peoples. It is important to note that these numbers while obtained from professional sources differ in the date that the statistics were obtained.

On a more positive note, the situation in most of these countries is improving. It has been admitted that for various reasons Indigenous people should be represented in the accounting profession. Strategies to increase the representation have also been set and in some countries implementation of these strategies has started. In South Africa for instance, the South African Institute of Charted Accountants set itself the target of having 3000 registered black accountants by 2005. In other words, the aim is for $25 \%$ of all South Africa's charted accountants to be black (Sadler, 2002) [17]. This would mean an increase of $23.94 \%$.

In Canada, a centre for excellence and innovation in aboriginal finance and management was created in 1999 and named the Aboriginal Financial Officers Association of Canada (AFOA). It should be noted that among all countries, this association represents the only group which has formed a professional accounting designation specifically for indigenous peoples. In addition, a pilot project targeting Canadian Aboriginal youth and urging them to complete high school and then pursue careers in accounting was launched in 2008 (Charted Accountants of Canada, 2008) [21]. In New Zealand, a National Maori Accountants Network has been developed as a special interest group of the New Zealand Institute of Chartered Accountants. Furthermore, in the United States, the Native American Finance Officers Association (NAFOA) was formed in 1982 but without having its own accounting designation.

\subsection{Barriers to Participation}

This section reviews the barriers to participation of indigenous people in accounting education and profession in each of the individual countries within the

Table 1. Participation in the accounting profession within marginalised ethnic groups and Indigenous peoples.

\begin{tabular}{ccc}
\hline Country Name & $\begin{array}{c}\text { \% Of Accountants who are } \\
\text { Indigenous }\end{array}$ & $\begin{array}{c}\text { \% of Total Population } \\
\text { who are Indigenous }\end{array}$ \\
\hline United States & 1 & 12 \\
Canada & 2.10 & 3.80 \\
South Africa & 1.06 & 79.40 \\
New Zealand & 0.8 & 14.60 \\
Australia & 0.006 & 2.80 \\
\hline
\end{tabular}

*The percentage for the United States represents African-Americans rather than Indigenous. 
historical contexts of European settlement and the institutions of indigenous discrimination in each of the countries. The objective is to contextualize the barriers of entry within the different societies, their structures and institutions.

\subsubsection{South Africa}

The European colonization of South Africa started when the Dutch East India Company decided to establish a permanent settlement in Table Bay in 1652 (Welsh, 1998) [22]. Initially the Company sought to meet its local needs through trading with the indigenous people, but this proved difficult and the company released a small number of Dutch from their contracts and permitted them to establish farms, with which they would supply the Company settlement from their harvests. This arrangement proved highly successful, producing abundant supplies of fruit, vegetables, wheat, and citrus fruits to prevent scurvy; they also later raised livestock. The small initial group of free burghers, as these farmers were known, steadily increased in number and were joined by numerous Germans as well as some Scandinavians and French Huguenots, who shared common Calvinists beliefs fleeing religious persecution in France under King Louis XIV (Welsh, 1998) [22]. In addition to establishing the free burgher system, the Company also began to import large numbers of slaves, primarily from Madagascar and Indonesia. These slaves often married Dutch settlers, and their descendants and became known as the Cape Coloureds and the Cape Malays. Some of the burghers began to take up a semi-nomadic pastoralist lifestyle, days of travel from the nearest European settlement. These were the first of the Trekboers (Wandering Farmers, later shortened to Boers), completely independent of official controls, extraordinarily self-sufficient, and isolated.

The decline of Dutch mercantile power in the late $18^{\text {th }}$ century led to British colonisation of the Cape in 1795 to prevent it from falling into French hands. British sovereignty of the area was recognised at the Congress of Vienna in 1815. The enormous economic opportunities that included agriculture and mining contributed to continued European settlement, dispossession of indigenous land leading to wars with indigenous people. Simultaneously there were ongoing conflicts between the British and English culminating in the first and second Anglo-Boer war of 1877 and 1899 (Welsh, 1998) [22]. Unlike other countries analysed in this study the European settlers remained a minority determined to maintain their domination of the majority putting in place institutions to control land ownership, right to vote, residential and social segregation formally known as apartheid (Welsh, 1998) [22]. Increasing local and international opposition to apartheid in the 1980s, including an armed struggle, widespread civil unrest, economic and cultural sanctions by the international community, and pressure from the anti-apartheid movement around the world finally led to its dismantling and the establishment of majority rule in 1994, A policy to increase the participation of indigenous people only officially began in 1994 and therefore 20 years old.

Apartheid played a significant role in segregating the society; it also made the 
acceptance of different society groups, who have different cultures and races more challenging (Hammond et al. 2007) [13]. As a result, black accounting firms still do not receive work from the private sector (Sadler, 2002) [17]. Racism and discrimination, not only in political and leadership levels, but also in organizations and particularly in accounting firms is a key element behind the low numbers of black South Africans in the accounting profession (Sadler, 2002) [17]. According to the Sadler (2002) [17] study, even after 1994 when discrimination was not legal anymore, and after the announcement of targeting a 3000 black CA by 2005, there were still other impediments such as:

limited supporting programmes, bright Students enter other professions; Accounting is only a stepping stone to other careers, for example banking, there is no network of black CAs, Blacks do not assist other blacks to develop; lack of career awareness programmes in schools, Textbooks are not black friendly; and Leading accounting firms still do not accept blacks and do not provide opportunities for their advancement (pp. 179-180).

It is admitted that the pass rate among black South Africans is relatively poor, and caused by broken secondary school education. In addition, deficiencies in the publicising of the profession among black communities have resulted in an overall poor participation in the accounting profession. Furthermore, the self-confidence of black accounting trainees was impacted as a result of African accountants were assigned to less responsibility in comparison with their white counterparts.

On the other hand, in spite of all these impediments the number of Black South African accountants is increasing, as a result of the efforts of the South African Institute o Charterd Accountants (SAICA) and the Association for the Advancement of Black Accountants of South Africa (ABASA), academic support programmes and the initiatives of the accounting profession. However, as Sadler (2002) [17] points out, the number is not yet anywhere near the desired target.

\subsubsection{United States of America (US)}

The US was the first of the five countries reviewed to be discovered by European explorers in 1492 and settled in 1607 (Carnes and Garraty, 2010) [23]. Whilst the British dominated early settlement different parts of US were colonized by different European colonizers mainly France and Spain. The diverse national affiliation and religious beliefs of the settlers also led to a rebellion against British Rule by thirteen colonies in 1775 and independence in 1789, (Carnes and Garraty, 2010) [23]. The initial US view of the George Washington administration was that Native Americans were equals but that their society was inferior.

As settlers continued to expand West a lot of indigenous people died, reducing their proportion in the total US population in 1890 to $0.2 \%$ (Carnes and Garraty, 2010) [23]. In 2010 the population of Native Americans in the US has recovered to 2.9 million or less that $1 \%$ of the total population-the lowest proportion in the five countries reviewed. For the above reasons there have been very few studies on the participation of indigenous people in accounting educa- 
tion and the profession, the participation of other minorities like the Blacks has received more attention in the literature (Greenhaus et al. 1990 and Moyes et al. 2000). The American Institute of Certified Public Accountants (AICPA) has focussed its attention on all minorities rather than a particular group and is led by the Minorities Initiative Committee (MIC which celebrated its 40 anniversary in 2009 with publication CPA's of Color (AICPA, 2009) [24].

According to Hammond (2002) [25], African-Americans are another group of people who are not part of the white middle class. Furthermore, Hammond (1997) [9] states that "African Americans were virtually barred from becoming certified public accountants until after the civil rights activism of the 1950s and 1960s led to legislation outlawing employment discrimination". Although, agreement on allowing the participation of black accountants in firms was made after seeing that diversity is good business sense (Hammond and Paige, 1999) [26]. Black African-Americans have experienced a similar situation as black South African Accountants, in that the nature of the work task assigned to them and their counterparts has been based on ethnicity and colour (Greenhaus et al. 1990 [27] and Moyes et al. 2000 [28]). In other words, the more mundane responsibilities are consistently assigned to marginalised group members, and the more challenging tasks "which develop the person's skills, and engage in wider network" are therefore assigned to white accountants. Therefore, cultural differences and discrimination inside the accounting profession had in the past and is in the present, will in the future lead to exclusion of the majority of marginalised ethnic groups from this particular field of work. For instance; Moyes et al (2000) [28] quote from their study the words of one of the black African-American professional accountants stating that "there is definitely a cultural difference that makes the minority hire feel uncomfortable".

James (2008) [29] asserts that low self-efficacy among African-American students for the required skills for either entering accounting classes or later joining the accounting profession has contributed to the under-participation. Not only that, but he also proposed that African-American students may choose careers other than accounting as a result of different work values. Brown (2002) [30] added that individuals may head towards a particular profession if a link between their work values and the perceived outcomes of that job exists. Consequently, differences in African-Americans' work values will raise the possibility of choosing a career other than accounting. Furthermore, James (2008) [29] asserted that lack of access to information about accounting may have driven African-Americans away from the accounting profession.

\subsubsection{Australia}

Australia and New Zealand were colonised much later than North America and South Africa. The first settlement of Australia was in 1788 when Captain Arthur Phillip entered Botany Bay with convicts, officials, marines and dependents to set up a penal colony (Broome, 2010) [31]. It was reported that 300,000 Indigenous Australians, divided into over 500 tribes, speaking more than 500 dialects 
were reportedly living in Australia (Broome, 2010) [31]. The British Government decided that Australia was "Terra Nullius"”, and took possession of it without asking the native inhabitants (Broome, 2010) [31].

Indigenous Australians were not considered Australian citizens and were not included in the population count even after Australia became an independent nation in 1901 (Lombardi \& Clayton, 2009) [32]. Initial Australian policy towards the indigenous people was similar as in US, Canada and New Zealand, that of assimilation including the removal of aboriginal children from their parents (Dudgeon, et al., 2010). Aboriginals' rights to the land were first recognised in Australia by the Aboriginal Land Rights Act 1976. The Act established the basis upon which Aboriginal people in the Northern Territory could claim rights to land based on traditional occupation. The statute, the first of the Aboriginal land rights acts, was significant in that it allowed a claim of title if claimants could provide evidence of their traditional association with the land. Aboriginal people in the rest of Australia, however, had to wait till 1992 for the Terra Nullius principle to be overturned by the High Court in the Mabo case and the enactment of the Native Titles Act 1993.

Until 2009 there was little research on the under-representation or efforts to address the underrepresentation (Lombardi \& Clayton, 2009 [32] and Rkein\& Norris, 2012 [7]). Rkein and Norris (2012), state that one of the possible reasons behind the under-representation in accounting classes was the lack of knowledge about accounting "Remote Indigenous students have no perception of what accounting' means and have not had contact with accountants'. Students in the Rkein and Norris 2009 [7] study were perceived to dislike the notion of spending their working hours in an office, tied to a desk and computer. In addition, the portion of the Indigenous students interviewed who had studied accounting as a subject in year 11 claimed that the classes were boring. It was also cited by them that culture has an influence on impeding Indigenous students from studying accounting in schools and universities and from later joining the accounting profession in two contexts:

Firstly, Indigenous children are taught to learn by doing but Western-style classes are less inclined toward that pedagogical approach. Secondly, the historical lack of a currency, the continuing acceptance of barter and swap and the culture of compulsion to share with the whole community were cited by a teacher as an impediment to the selection of accounting. One can see that these

${ }^{2}$ The prevailing international (European) law concerning the ownership of newly "discovered" lands held that the inhabitants only had sovereignty over that land if, by their labour and practice of agriculture, they used it and changed it by constructing buildings and towns. If the Europeans "discovered" lands inhabited by an agricultural people with recognisable systems of government, possession of that land could be taken by the European "discoverers' only with the consent of the inhabitants. However if the land was either uninhabited, or inhabited by a people who did not use the land (in the European sense of use) then according to prevailing ideas of international law it could be freely taken... on the basis of the Eurocentric and largely mistaken observations of Captain Cook and others that the Aborigines were few in number, wore no cloths, did not till the soil and had no buildings or observable forms of government, the British decided to take possession of the land without asking the native inhabitants (Broome, 1982. p.26). 
cultural norms would impede the understanding of accounting principles and practices and the recognition of the need for accountants (Rkein \& Norris, 2012 (7)).

The fact that this profession is based on building the individual wealth within a capitalist system, whereas on the other hand Indigenous societal system is based on totally different perspectives such as kinship and community (Lombardi \& Clayton, 2009 [32]) culture was also accepted as one of the main reasons that lies behind the under-representation of Indigenous peoples in the accounting profession. In addition, segregating the Indigenous individual from his or her community is extremely difficult, as a result Indigenous students tend to choose careers that can be performed within their communities, and unfortunately accounting was not seen as a profession that can fit there (Rkein \& Norris, 2012).

Furthermore, Indigenous education cannot be ignored when looking into what reasons might result in low participation of Indigenous people in the accounting profession. Owing to the fact that the Australian education system is still seriously failing Indigenous students (Bartlett, 2007) [33] at all levels of schooling Indigenous students continue to be under-represented, compared to non-indigenous students (Hauser et al., 2009) [34]. Irrespective of whether the reasons are due to culture, the nature of tertiary education, the lack of Indigenous educators and/or any other reasons, Indigenous students are disadvantaged when approaching higher education in urban universities and their likelihood of failure is constantly increasing.

\subsubsection{Canada}

Canada whilst discovered by Europeans around the same time as US was settled by the French and English around the mid $16^{\text {th }}$ century. Unlike South Africa, Australia and the US, colonization of Canada was through a series of treaties between the colonizers and the Crown similar to that in New Zealand. Similar to colonial policies in South Africa, US, and Australia, the initial focus was on assimilation of indigenous people into European culture in the $19^{\text {th }}$ and early $20^{\text {th }}$ century (Royal Commission on Aboriginal Peoples, 1996) [35]. The Indian Act that dates back to 1876 indicates how Reserves and Bands can operate and defines who is recognized as an "Indian". The Royal Commission on Aboriginal Peoples was a Royal Commission undertaken by the Government of Canada in 1991. It recommended major changes to government policy and this led to Aboriginal rights to self government.

Canadian Indigenous employees have always faced significant obstacles when trying to enter non-Indigenous organisations. Volume two of the Report of the Royal Commission of Aboriginal Peoples: Restructuring the Relationship (Royal Commission on Aboriginal Peoples, 1996, p. 937) [35] sheds light on some of these obstacles. The following is a statement made by a Canadian Indigenous:

How was I [an Aboriginal] supposed to deal with a manager and a system that continually sought to treat me as a child? I have both a Bachelor's and Master's 
degree, and their tactics included requests that I submit all of my calculations for verification by a supervisor, ostensibly because they couldn't be sure my totals were correct. No other person among my forty-three co-workers was required to do this. They told me that my work was being checked because I grew up on a reserve where nobody learned to add properly.

Again discrimination in the work place, distrust, and an unfriendly work environment play the most remarkable role in impeding Canadian Indigenous from entering specific professions. As can clearly be seen from the previous statement, a precise indication was given to calculation and adding which according to many researchers has been linked to accounting (Jackling and Calero 2006 [36], Maldenovic 2000 [37], Parker 2001 [38], Wong and Chia 1996 [39], Hartwell et al. 2005 [40] and Mitchell 1985 [41]). As a result, Canadian Indigenous peoples were driven away from a profession that has a perception of a strong relationship with numbers and counting.

As in other countries, there is an undeniable gap between Canadian Indigenous peoples' culture and traditions, and Western governmental system as it is implemented in Canada. Because of this system, of which the accounting system is emphatically a part of, Canadian Indigenous people are under-represented in the accounting profession. As an illustration, a report prepared for the Public Service Commission of Canada in 1991 entitled "A Study on the Retention of Aboriginal Peoples in the Federal Public Service" made the following observations:

...For many, entry (to a profession) involves a culture shock which comes in a variety of guises. The language of the bureaucracy and formalities of government create uneasiness for many Aboriginal peoples. They feel conflicts between their traditional ways and accepted government practices. The bureaucratic levels and systems within government are also foreign. The environment is perceived to be fiercely competitive, filled with roadblocks to advancement, and with people looking out only for themselves. The individualistic way in which work is done is perceived to be alien and pressure packed (Public Service Commission of Canada, 1991, p. 16 [42]).

Thus, complete ignorance of Indigenous culture in a countries' governmental system neutralises its plan to give full work participation rights to the country's Indigenous peoples. As a result, Canada is as guilty as the other countries in ignoring the cultures and traditions of its Indigenous peoples, who will consequently avoid entering the accounting profession. One of the responses to the Report of the Royal Commission on Aboriginal Peoples (Royal Commission on Aboriginal Peoples, 1996 [35]) was the establishment of the Aboriginal Financial Officers Association (AFOA) in 1999 with a mandate "to help Aboriginals better manage and govern their communities and organizations through a focus on enhancing finance and management practices and skills" (Aboriginal Financial Officers Association, 2009) [18]. The AFOA has grown into an organization with over 1300 members in eight regional chapters and it is unique in that it is the 
only Aboriginal association, globally, that has established a professional accounting designation geared to Aboriginal peoples (Buhr, 2011) [1].

\subsubsection{New Zealand}

Of the five countries included in this study, New Zealand was the latest country to be settled officially in 1840 with the signing of the Treaty of Waitangi. The Treaty was represented as having three objectives: the protection of Maori interests, the promotion of settler interests and the securement of strategic advantage for the Crown (Adams, 1977 [43]; Durie, 1998 [44]). For the British, the Treaty was a means by which they gained control over Aotearoa/New Zealand. For Maori the Treaty was an important document in which greater recognition of Maori authority was granted, but subsequently marks more than 150 years of adverse conditions under European rule and the loss of Rangatiratanga (independent authority/chieftainship) (True, 1996 [45]).

Similar to settler policy in the other four countries, initial government policy was assimilation into British society (McNichols et al., 2004) [6]. The 1961 Hunn Report drew attention to injustices and inequities in socio-economic policy that had disadvantaged Maori (Durie, 1997) [44]. A major turning point in the Crown's reconciliation with Maori was the establishment of the Waitangi Tribunal in 1975 following protests about unresolved Treaty of Waitangi grievances. In the 2013 Census, 598,605 people were identified as being part of the Māori ethnic group, accounting for $14.9 \%$ of the New Zealand population, while 668,724 people (17.9\%) claimed Māori descent (Statistics New Zealand, 2013) [46].

It is not only cultural differences, but also the contradiction between cultural values and the accounting system, which was imposed to ensure the full dominance by white authorities over the Maori societies. The socioeconomic status for Maori people has also affected the low participation of the Maori people in the accounting profession (Gallhofer et al., 1999) [47]. For instance, in their study McNicholas and Humphries (2005) [48] indicated that Maori women accountants when involved in the culture of the organizations in which they work, struggle to protect their culture from being lost and to maintain their identity as a Maori. Furthermore, under-participation of New Zealand Indigenous people in the accounting profession is also seen as a result of educational problems. The Maori peoples' educational underachievement is attributed to the inappropriate education system, and to their economic status which continues to be considerably lower than that of other new Zealanders (Statistics New Zealand. 2002) [49]. As a result of their different cultures, Maori people have different work values. Therefore, incentives and encouragements from certain professional bodies to attract more people from the society into the accounting profession, fail to attract Indigenous peoples who require totally different incentives to undertake any type of career. In 2002 Maori accountants formed the National Maori Accountants Network to promote Mari in the accounting profession. 


\subsection{Common Themes}

The review of the literature highlights a number of common themes on the barriers to indigenous participation in accounting education and profession. The themes are not mutually exclusive and frequently overlap. The themes are:

- Discrimination (specific accountants were not allowed in the profession, because of their colour, race and or ethnicity, also based on these they were assigned to less challenging jobs)

- Self efficacy (Indigenous people assumes that they cannot meet the entry requirements for entering the accounting profession, as a result they have a low self efficacy towards the accounting profession)

- Cultural differences (inside the work place, only Western culture existed and Indigenous accountants struggled to remain, or due to accounting system that does not consider Indigenous cultures)

- Lack of knowledge (Indigenous people have lack of access to information about accountancy and what accounting can do)

- Numeracy/Literacy (Indigenous education and particularly their literacy and numeracy levels are lower than that of their non-Indigenous counterparts)

\subsubsection{Discrimination}

In societies where more than one culture is found, individuals are regularly uncomfortable with others of a different culture and race (Moyes, et al., 2000) [28]. In their paper, the authors frequently asserted that trainees from marginalised groups fear to ask questions. Ethnic stereotypes might be the result of asking questions which is assumed to be the result of lack of information. Such a feeling among minority ethnic groups is a result of discrimination. Irrespective of whether it is "access discrimination" where marginalised ethnic and colour groups are prevented from entering a particular profession or "treatment discrimination", where different ethnicity group members look at their colleagues' race and colour inside the profession instead of their qualifications and achievements (Greenhaus, et al. 1990, p. 64) [27]. It should be noted that discrimination sometimes can be unintentional, and, as such, it is more difficult to counteract than deliberate malicious discrimination, because the perpetrators cannot accept that they are being discriminatory.

Relevant literature indicates that in countries such as the United States, Canada and South Africa, discrimination exists, either inside the profession and/or before entering the profession. In Australia, however, although discrimination inside the accounting profession has not yet been researched, discrimination in the workplace in general have been researched and reported. Discrimination inside the accounting professions in Australia is another project that the authors of this paper are going to explore later in further publications. In Australia racist attitudes in the work place have resulted in a lack of respect for indigenous people from their colleagues (Murray, 1997) [50].

\subsubsection{Self Efficacy}

Discrimination has a major impact on self efficacy. The lack of respect will 
doubtless lead to lower self confidence and less efficacy, which according to the literature, played a remarkable role in the under-participation of Indigenous people in the accounting profession in Canada, South Africa and United States. Evidences were provided earlier to show that Indigenous employees were targeted by their supervisors in order to decrease their self confidence, for instance through less important task assignments and unnecessary revision of work.

The Canadian initiative in the establishment of the Aboriginal Financial Officers Association (AFOA) in 1999 with a mandate "to help Aboriginals better manage and govern their communities and organizations through a focus on enhancing finance and management practices and skills" (Aboriginal Financial Officers Association, 2011) [18] is a useful means of improving the self-efficacy of indigenous accounting professionals.

\subsubsection{Culture Differences}

The factor of cultural differences is common among all countries and as a result, Indigenous people do not feel comfortable working in an environment where a different culture exists. As the literature indicated, Indigenous peoples struggle while working in order to preserve their identity which is identified by their culture. For this reason, Indigenous people set their own work values which frequently conflicts with that of non Indigenous people. Therefore, Indigenous peoples are seen in some professions more than in others. In some professions, cultural differences are less noticeable than in others. More importantly, Indigenous Australians work values take into account the Indigenous peoples' ultimate goal of going back to their communities, therefore, work values will be determined by a person's consideration of the needs of his or her home community.

Furthermore, career choices among different ethnic groups might also play a significant role, when directing a certain portion of the society into a specific profession, thus resulting in the avoidance of another. The most commonly held view is that careers are either a result of individual choice and initiative, or in view of people's social and economic milieu based on the availability of options in the society (Arthur, 1990 [51] and Watson 1995 [52]). A further theory suggests that career choices are also influenced by family values, class background, and societal values or culture (Derr and Laurent 1989 [53]). Watson (1995) [52] in particular has pointed out that in cultures which value family and personal relationships, people will avoid stressful careers which might put a strain on these relationships (Watson 1995 [52]).

\subsubsection{Lack of Knowledge}

Among all these countries it has been reported that a lack of information and knowledge of how to access the accounting profession has contributed to the under-representation of indigenous people in the profession. Although all countries, except Australia and New Zealand, have devised strategies to encourage marginalized ethnic groups to join the accounting profession, there is still a gap between the quality and quantity of information that a non Indigenous person and an Indigenous person has access to. 


\subsubsection{Numeracy/Literacy}

Education levels among indigenous groups have also contributed to the under-representation of these groups in the accounting profession. Regardless of whether the low literacy and numeracy levels were a result of cultural issues or poor preparation in primary and secondary schools, they contributed to an increase to the under-participation in the accounting profession in all of the discussed countries.

\subsection{Institutions and Under-Representation}

In the previous section we have looked at the common themes that have been identified as barriers to indigenous participation in accounting education and profession, however there is little research on the institutional causes of these barriers. In this section we will examine the possible institutional causes of the barriers and future directions for research.

A common theme in the literature on accounting and indigenous people and accounting is how accounting has been used a tool for dispossession. Hooper and Pratt (1995) [12] and Hooper and Kearins (1997 [54], 2004 [55], 2008 [56]) detail how accounting has been used to acquire Maori land and help to overturn social arrangements. The indigenous literature has however ignored the importance of property and indigenous participation in the economy for participation. People seek education in areas which is relevant to their communities. This view is supported by the fact that the US evidence shows minority participation in the American Medical Association, the American Bar Association, and the AICPA, they make up $14 \%, 10 \%$, and $8 \%$ of their respective professions. The indigenous participation in the medical and legal profession is much higher than that in accountancy. This can be attributed to the healthcare needs and civil and property rights battles with the state in many of these countries. For example the National Association for the Advancement of Colored Peoples (NAACP) was formed in 1909 and Thurgood Marshall, a Black lawyer and Chief Counsel of the NAACP became a member of the Supreme Court in 1967.

Indigenous people have generally been at the margins of the economy in all the five countries for two major reasons; dispossession of their property and culture. Property and/or compensation were only given to indigenous people, beginning in the 1970's in some countries and as late as the 1990's in other countries. The lack of private property, property rights and culture of communal property in many indigenous societies has prevented indigenous people from effectively participating in the economy. A major debate in accounting is whether it is socially constructed or socially constructing. It is not the objective of this paper to debate the issue. A study of the relationship of indigenous economy and indigenous participation in accounting is essential to promote the participation of indigenous people in the profession.

A second theme that is common in the indigenous accounting literature is the policy of assimilation that was adopted in all the five countries by the European settlers. It is pointed out that indigenous people have different value systems, 
cultures and languages and they are not fully recognized or given space. Greer and Patel (2000) [57] speak about the conflict of values between Aboriginal ideas concerning work and land and Western capitalistic ideas. Gallhofer and Chew (2000) [2] assert that Indigenous values can offer insights and transform Western values for the better. They say that one area where this is especially needed is the environmental crisis. Holmes et al. (2005) [10] detail the accounting practices employed by the Franciscans in the 1700s which "extracted power from the indigenous population and led them to exchange their native beliefs for Western values" (p. 106).

The lack of self efficacy among indigenous people can be attributed to the assimilation policy of colonial governments in the five countries. Alfred (2009) [58] argues that forced removal from the land or being denied access to the land to continue traditional cultural activities contributed to create near total psychological, physical and financial dependency on the state. Duran and Duran (1995) [59] characterises the problem as follows:

Once a group of people have been assaulted in a genocidal fashion, there are psychological ramifications. With the victim's complete loss of power comes despair, and the psyche reacts by internalizing what appears to be genuine power-the power of the oppressor. The internalizing process begins when First Nation American people internalize the oppressor, which is merely a caricature of the power actually taken from First Nation American people. At this point, the self worth of the individual and/or group has sunk to a level of despair tantamount to self-hatred (p. 29).

The Canadian Royal Commission on Aboriginal Peoples (RCAP) studied the problem of dependency in the context of colonialism as one of the main focuses of its work, and developed an extensive research program involving all of the country's expertise, individually and institutionally, on this subject. It concluded that self-government and the return of traditional lands would go a long way towards recovery and empowerment of indigenous people. Whilst the above policy has gained near universal acceptance and has been adopted in all the five countries, its impact on indigenous economic development is difficult to assess. In some countries, e.g., Australia the government has rolled back the degree of self governance (Altman and Russell, 2012) [60].

Whilst the above policies have considerable success in the regeneration of their culture and recovery of indigenous accountability systems (Buhr, 2011) [1], we need to ask how this will help indigenous people navigate the dominant Western economic system outside the indigenous communities. The two authors of the paper are migrants to two of the countries in this study from different non European countries. To succeed in the countries they have had to assimilate and adapt to the dominant social and workplace culture and it is the government policy in all the above countries that migrants need to assimilate. Of course there is a difference, migrating is a voluntary decision and therefore an implicit recognition of the need to adopt, while indigenous people were forced to adopt a foreign culture and systems in their homeland. Survey of Indigenous students and 
teachers by Rkein and Norris (2012) [7] indicates that Australian Aboriginal practice of barter and swap could be an impediment to learning Western accounting. The question is, will the rediscovery of indigenous culture help indigenous people navigate the Western economic system.

\subsection{Limitation and Future Research}

Although this study has provided a foundation for the study of low participation of indigenous people in accounting, it nonetheless has a number of limitations. For example, the research was carried out by a non-Indigenous researcher. The researcher has been living and working with Indigenous peoples and societies in the Northern Territory for a decade, but he still lacks a truly in-depth understanding of Indigenous lives, cultures and traditions. This limitation was compounded in the literature review chapter, where most of the reported research was conducted by non-Indigenous researchers and therefore many of their studies were open to the same criticism.

This research should encourage future researchers to engage in studies which include Indigenous participants to seek their views. Furthermore, future studies could include in their data collection a number of the factors which this study has revealed as barriers to participation. Indigenous participants should also be invited to participate and asked to be interviewed as they may add additional factors that have not been thought of previously. This can then help in a strategy that can be put in place to tackle the issue of under participation.

\subsection{Conclusions}

There is wide acceptance that accounting not only played a role in the dispossession of indigenous land but also their disempowerment through the destruction of their culture and traditional governance systems. It can therefore be argued that accounting could probably play a role in their social and economic development. The participation of indigenous people in accounting education and profession is very low in comparison to other professions like medicine and law. Whilst there are a number of individual country studies on the reasons for this low participation, there is no comparative study. We believe that an international comparison will be invaluable because indigenous people in the countries colonised by the British have generally had similar colonial experiences.

The comparative study highlights five main themes contributing to the under-representation of Indigenous peoples in accounting education and profession, namely discrimination in the workplace, poor self efficacy, cultural differences, poor knowledge of accounting, and lastly poor literacy and numeracy skills. The themes can be related to a number of colonial institutional practices, principally the dispossession of indigenous property and assimilation. Indigenous peoples have argued that the above colonial practices have contributed to near total psychological, physical and financial dependency on the state. The main policy response to poor social and economic conditions in all the five main countries has been the return of traditional land to indigenous people and the 
granting of limited self governance. In conjunction with the above institutional practices there are suggestions in the literature that the rediscovery of pre-colonial record-keeping practices among Indigenous peoples, traditional accountability practices and indigenous professional bodies.

In this paper we suggest that whilst the return of traditional land might provide a base for Indigenous peoples to participate in the economy through businesses and also empower them there is considerable more research required to determine whether the rediscovery of traditional culture and institutional practices will help Indigenous peoples participate in mainstream economy.

\section{Acknowledgements}

We like to acknowledge the support received by CPA Australia to conduct the research project of which this paper forms one part.

\section{References}

[1] Buhr, N. (2011) Indigenous Peoples in the Accounting Literature: Time for a Plot Change and Some Canadian Suggestions. Accounting History, 16, 139-160. https://doi.org/10.1177/1032373210396334

[2] Gallhofer, S. and Chew, A. (2000) Introduction: Accounting and Indigenous Peoples. Accounting, Auditing and Accountability Journal, 13, 256-267. https://doi.org/10.1108/09513570010334081

[3] Annisette, M. and Neu, D. (2004) Accounting and Empire: An Introduction. Critical Perspectives on Accounting, 15, 1-4.

[4] Smith, L.T. (1999) Decolonizing Methodologies: Research and Indigenous Peoples. Zed Books Ltd., London.

[5] Helin, C. (2008) Dances with Dependency: Out of Poverty through Self-Reliance. 2nd Edition, Ravencrest Publishing, Woodland Hills.

[6] McNicholas, P., Humphries, M. and Gallhofer, S. (2004) Maintaining the Empire: Maori Women's Experiences in the Accountancy Profession. Critical Perspectives on Accounting, 15, 57-93.

[7] Rkein, H. and Norris, G. (2012) Barriers to Accounting: Australian Indigenous Students' Experience. Social and Environmental Accountability Journal, 32, 95-107.

[8] Hammond, T. and Streeter, D. (1994) Overcoming Barriers: Early African-American Certified Public Accountants. Accounting, Organizations and Society, 19, 271-288.

[9] Hammond, T. (1997) From Complete Exclusion to Minimal Inclusion: African Americans and the Public Accounting Industry: 1965-1988. Accounting Organisations and Society, 22, 29-53.

[10] Holmes, S.A., Welch, S.T. and Knudson, L.R. (2005) The Role of Accounting Practices in the Disempowerment of the Coahuiltecan Indians. Accounting Historians Journal, 32, 105-143. https://doi.org/10.2308/0148-4184.32.2.105

[11] Preston, A.M. (2006) Enabling, Enacting and Maintaining Action at a Distance: An Historical Case Study of the Role of Accounts in the Reduction of the Navajo Herds. Accounting, Organizations and Society, 31, 559-578. https://doi.org/10.1016/j.aos.2005.03.003

[12] Hooper, K. and Pratt, M. (1995) Discourse and Rhetoric: The Case of the New 
Zealand Native Land Company. Accounting, Auditing \& Accountability Journal, 8, 10-37. https://doi.org/10.1108/09513579510079108

[13] Hammond, T., Arnold, P.J. and Clayton, B.M. (2007) Recounting a Difficult Past: A South African Accounting Firm's "Experiences in Transformation". Accounting History, 12, 253-281. https://doi.org/10.1177/1032373207079027

[14] Mitchell, B. and Flintall, V. (1990) The Status of the Black CPA: Twenty Year Update. Journal of Accountancy, 176, 59-69.

[15] Jacobs, K. (2000) Evaluating Accountability: Finding a Place for the Treaty of Waitangi in the New Zealand Public Sector. Accounting, Auditing \& Accountability Journal, 13, 360-380. https://doi.org/10.1108/09513570010334919

[16] Hantrais, L. (1995) Comparative Research Methods. Social Science Research Update 13, University of Surrey, Guildford. http://sru.soc.surrey.ac.uk/SRU13.html

[17] Sadler, E. (2002) A Profile and the Work Environment of Black Chartered Accountants in South Africa. Meditari Accountancy Research, 10, 159-185. https://doi.org/10.1108/10222529200200009

[18] Aboriginal Financial Officers Association (2011) AFOA Membership Report.

[19] Ministry of Maori Development (1999) Maori in the New Zealand Economy. Ministry of Maori Development, Wellington.

[20] New Zealand Institute of Chartered Accountants (NZICA) (2013) NZICA Annual Report. NZICA, Wellington.

[21] Charted Accountants of Canada (2008) Martin Aboriginal Initiative and the Chartered Accountants of Canada Team up for pilot Project. Charted Accountants of Canada.

[22] Weschler, D. (1998) The Class of 65. Forbes, 7, 92-98.

[23] Carnes, M.C. and Garraty, J.A. (2008) The American Nation: A History of the United States. Earson, New York.

[24] American Institute of Certified Public Accountants (AICPA) (2009) CPAs of Color: Celebrating 40 Years.

http://www.aicpa.org/Career/DiversityInitiatives/DownloadableDocuments/MIC_E -Book2541-331.pdf

[25] Hammond, T. (2002) A White-Collar Profession: African American Certified Public Accountants since 1921. University of North Carolina Press, Chapel Hill.

[26] Hammond, T. and Paige, K. (1999) Still Seeking the Ideal. Journal of Accountancy, 75-79.

[27] Greenhaus, J.H. and Wormley, W.M. (1990) Effects of Race on Organizational Experiences. Academy of Management Journal, 33, 64-86.

https://doi.org/10.2307/256352

[28] Moyes, G.D., Williams, P.A. and Quigley, B.Z. (2000) The Relation between Perceived Treatment Discrimination and Job Satisfaction among African-American Accounting Professionals. Accounting Horizons, 14, 21-48. https://doi.org/10.2308/acch.2000.14.1.21

[29] James (2008) Barriers to Accounting as a Career Choice for African-American Students. Research in Higher Education Journal, 6, 558-567.

[30] Brown, D. (2002) The Role of Work and Cultural Values in Occupational Choice, Satisfaction, and Success: A Theoretical Statement. Journal of Counseling and Development, 80, 48-56. https://doi.org/10.1002/j.1556-6678.2002.tb00165.x

[31] Broome, R. (2010) Aboriginal Australians: A History since 1788. Allen Unwin, 
Sydney.

[32] Lombardi, L. and Clayton, B.M. (2009) The Path Less Travelled: Indigenous Australians and the Accounting Profession. Paper Presented at the 2009 Interdisciplinary Perspectives on Accounting Conference, Innsbruck.

[33] Bartlett, A. (2007) Australian Democrats Plan Indigenous Education. http://www.democrats.org.au

[34] Hauser, V., Howlett, C. and Matthews, C. (2009) The Place of Indigenous Knowledge in Tertiary Science Education: A Case Study of Canadian Practices in Indigenising the Curriculum. The Australian Journal of Indigenous Education, 38, 46-57.

[35] Royal Commission on Aboriginal Peoples (1996) Report of the Royal Commission of Aboriginal Peoples. Minister of Supply and Services Canada, Ottawa.

[36] Jackling, B. and Calero, C. (2006) Influences on Undergraduate Students' Intentions to become Qualified Accountants: Evidence from Australia. Accounting Education: An International Journal, 15, 419-438.

[37] Mladenovic, R. (2000) An Investigation into the Ways of Challenging Introductory Accounting Students' Attitudes towards Accounting as a Profession. Accounting Education: An International Journal, 12, 113-133.

[38] Parker, L.D. (2000) Goodbye, Number Cruncher. Australian CPA, 70, 50-52.

[39] Wong, D.S.N. and Chia, Y. (1996) English Language, Mathematics and First-Year Financial Accounting Performance: A Research Note. Accounting Education, 5, 183-189.

[40] Hartwell, C.L., Lightle, S.S. and Maxwell, B. (2005) High School Students' Perceptions of Accounting.

[41] Mitchell, F. (1985) School Accounting Qualification and Student Performance in a First Level University Accounting Examination. Accounting and Business Research, 15, 81-86. https://doi.org/10.1080/00014788.1985.9729249

[42] Public Service Commission of Canada (1991) A Study on the Retention of Aboriginal Peoples in the Federal Public Service. Review Directorate, Ottawa.

[43] Adams, P. (1977) Fatal Necessity: British Intervention in New Zealand, 1830-1847. Oxford University Press, Auckland.

[44] Durie, M. (1997) Whaiora Maori Health Development. Oxford University Press, Auckland.

[45] True, J. (1996) Fit Citizens for the British Empire? Classifying Racial and Gendered Subjects in "Godzone" (New Zealand). In: Williams, B.F., Ed., Women out of Place. The Gender of Agency and the Race of Nationality, Routledge, New York, 71-85.

[46] Statistics New Zealand (2013) 2013 Quick Stats about Maori: Census 2013. Statistics New Zealand, Wellington.

[47] Gallhofer, S., Haslam, J., Kim, S.N. and Mariu, S. (1999) Attracting and Retaining Maori Students in Accounting: Issues and Experiences and Ways Forward. Critical Perspectives on Accounting, 10, 773-807. https://doi.org/10.1006/cpac.1998.0282

[48] McNicholas, P. and Humphries, M. (2005) Decolonization through Critical Career Research and Action. Australian Journal of Career Development, 14, 30-39. https://doi.org/10.1177/103841620501400106

[49] Statistics New Zealand (2002) Census Snapshot: Maori. Statistics New Zealand, Wellington.

[50] Murray, M. (1997) Overcoming Workplace Barriers for Aboriginal People. Director of Equal Opportunity in Public Employment, Western Australia. 
[51] Arthur, W.S. (1990) Torres Strait Development Study 1989. Australian Institute of Aboriginal Studies, Canberra.

[52] Watson, T.J. (1995) Sociology, Work and Industry. Routledge, London.

[53] Derr, C.B. and Laurent, A. (1989) The Internal and External Career: A Theoretical and Crosscultural Perspective. In: Arthur, M.B., Hall, D.T. and Lawrence, B.S., Eds., Handbook of Career Theory, Cambridge University Press, Cambridge, 454-471.

[54] Hooper, K. and Kearins, K. (1997) The Excited and Dangerous State of the Natives of Hawkes Bay: A Particular Study of Nineteenth Century Financial Management. Accounting, Organizations and Society, 22, 269-292.

[55] Hooper, K. and Kearins, K. (2004) Financing New Zealand 1860-1880: Maori Land and the Wealth Tax Effect. Accounting History, 9, 87-105. https://doi.org/10.1177/103237320400900205

[56] Hooper, K. and Kearins, K. (2008) The Walrus, Carpenter and Oysters: Liberal Reform, Hypocrisy and Expertocracy in Maori Land Loss in New Zealand 1885-1911. Critical Perspectives on Accounting, 19, 1239-1262. https://doi.org/10.1016/j.cpa.2007.02.004

[57] Greer, S. and Patel, C. (2000) The Issue of Australian Indigenous World-Views and Accounting. Accounting, Auditing and Accountability Journal, 13, 307-329. https://doi.org/10.1108/09513570010334793

[58] Alfred, G.T. (2009) Colonialism and State Dependency. Journal of Aboriginal Health, 5, 42-60.

[59] Duran, E. and Duran, B. (1995) Native American Postcolonial Psychology. State University of New York Press, Albany.

[60] Altman, J. and Russell, S. (2012) Too Much "Dreaming": Evaluations of the Northern Territory National Emergency Response Intervention 2007-2012. Evidence Base, 2012, 1-28. 